\title{
Internet of things and fuzzy logic for smart street lighting prototypes
}

\author{
Mindit Eriyadi ${ }^{1}$, Ade Gafar Abdullah ${ }^{2}$, Hasbullah $^{3}$, Sandy Bhawana Mulia \\ ${ }^{1}$ Department of Electrical Engineering, Politeknik Enjinering Indorama, Indonesia \\ ${ }^{2,3}$ Department of Electrical Engineering, Universitas Pendidikan Indonesia, Indonesia \\ ${ }^{4}$ Department of Manufacturing Automation Engineering and Mechatronics, Politeknik Manufaktur Bandung, Indonesia
}

\begin{tabular}{l} 
Article Info \\
\hline Article history: \\
Received Mar 10, 2020 \\
Revised May 25, 2021 \\
Accepted Jun 2, 2021 \\
\hline
\end{tabular}

\section{Keywords:}

Energy saving

Fuzzy logic

Internet of things

Light intensity

Lux sensor

Smart street lighting

\begin{abstract}
Internet of things (IoT) and fuzzy logic are very useful in increasing the efficiency and effectiveness of a system; this study applies both to the street lighting systems. The prototype of a street lighting control and monitoring system has been completed. The status of lights that are on or off and the value of the light intensity can be monitored by using IoT. The intensity of the light is fuzzy controlled by utilizing the presence of vehicles and pedestrians around the lights. The prototype is made with a scale against real conditions. Data is processed and transmitted using a microcontroller and Wi-Fi on the IoT module. Mobile applications have been used on smartphone interfaces to monitor and control lamps wherever they are connected to the Internet. Changes in the status of lights to turn on or off are done by the relay module. The fuzzy light intensity control system uses sensors and microcontrollers by utilizing the presence of vehicles and pedestrians around the lights. Performance evaluation has been carried out on a miniature street lighting with the results of monitoring and control following its function. An analysis of the resulting energy savings has been demonstrated.
\end{abstract}

This is an open access article under the CC BY-SA license.

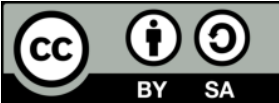

\section{Corresponding Author:}

Mindit Eriyadi

Department of Electrical Engineering

Politeknik Enjinering Indorama

Gedung C3, Jalan Desa Kembang Kuning, Kecamatan Jatiluhur,

Kabupaten Purwakarta, Jawa Barat, Indonesia

Email: mindit.eri@gmail.com

\section{INTRODUCTION}

Street lights today consume a lot of energy due to the poor intensity and efficiency controls [1], [2]. The current problem with conventional systems is long operating hours which cause a lot of electricity costs and are a big waste if not taken seriously [3]-[5]. Currently, streetlight technology, especially in public buildings, is still relatively traditional with minimal means of measuring how much light enters the street and the old reliability standards and sometimes does not take advantage of the new technical growth [6], [7]. Efforts have been made to efficiently consume public street lighting energy [8].

Interactions that do not require physical touch and the ability to send or receive data over a network because of its association with the environment can be defined as the Internet of things (IoT) [9]. IoT has automatic remote control capabilities that have a dominant impact on energy efficiency and organized energy management [9]-[12]. Fuzzy logic is currently increasingly used in various studies [13]-[15]. Comprehensive utilization of IoT and fuzzy logic functions can produce smart systems. The demand for smart street lighting for developed roads and highways has increased [16]. 
In this research, IoT is used to monitor and control lamp conditions in two conditions and to read the value of lamp light intensity so that they can monitor lamp damage conditions. The ability to monitor using IoT is combined with the use of fuzzy logic to adjust the light intensity automatically based on the presence of cars and pedestrians. A prototype was made to test the function of each part. Testing and analysis are performed on the use of the IoT function and fuzzy logic. System reliability testing, integrated system [17], component layout, some modification of algorithm for increase energy saving, and using the international standard [18] and security [19] for street lighting can be carried out at a later stage.

\section{RESEARCH METHOD}

This research resulted in a prototype based on a survey of public road lighting conditions that have been carried out. The survey was conducted to take a road sample that will form the prototype of a smart system. Figure 1 shows the stages of research that have been done.

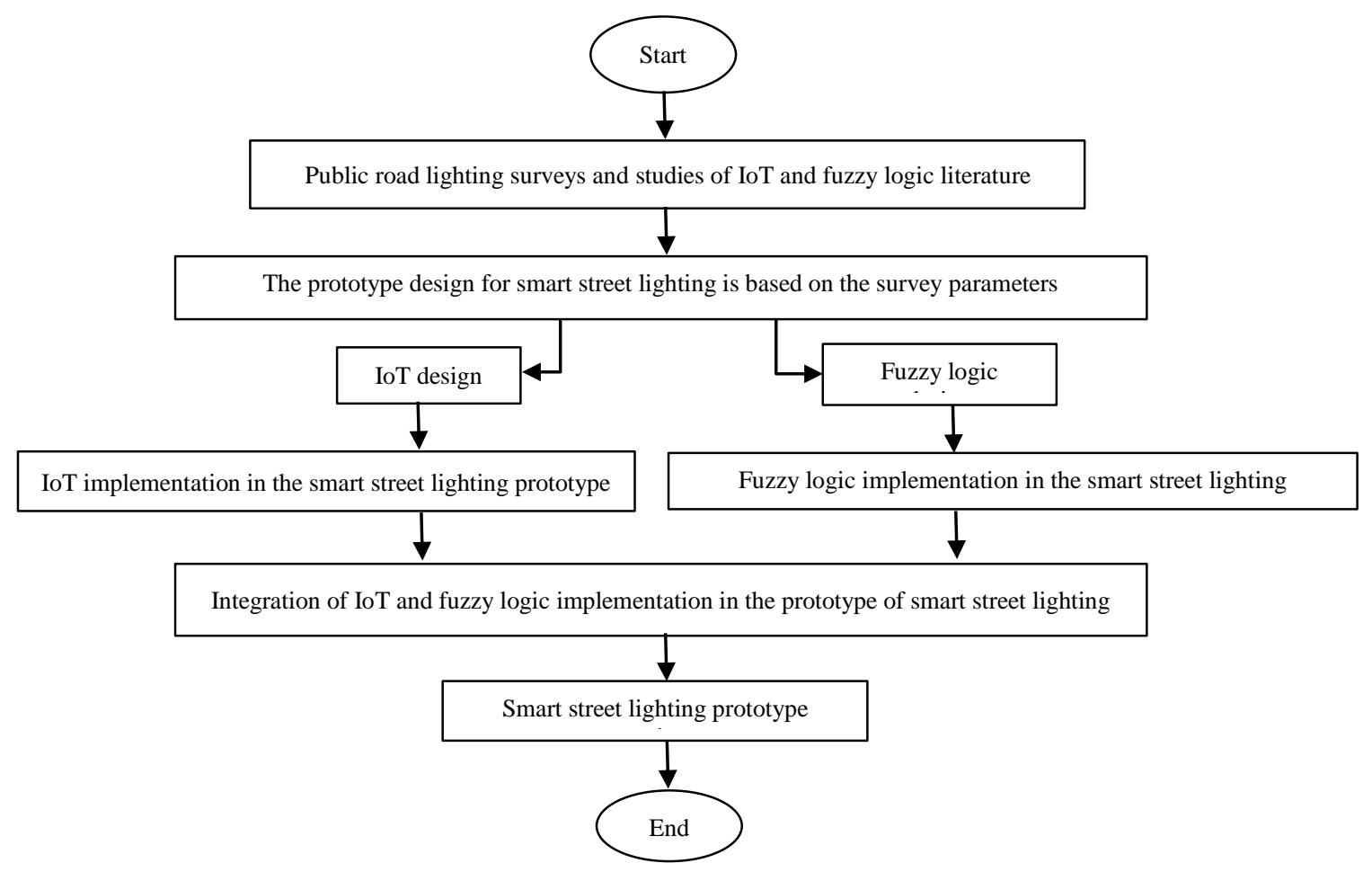

Figure 1. Research flowchart

The study of AnkalKote and Shere [20] is aimed at reducing energy consumption and hazardous ambient pollution on highway lighting systems with an intensity regulation dependent on vehicle movements and atom-structural conditions. In Caldo et al.'s research, Arduino microcontrollers were also used to introduce a flushing logic controller to dimming the display [13]. Research from Abdullah et al. [21] has concluded that smart street lighting using Arduino, light dependent resistor (LDR), infrared, batteries, and LEDs have reduced electrical energy consumption by up to $40 \%$ to $45 \%$ per month. The public road lighting survey in this study uses the direct measurement method for public road samples as shown in Table 1.

Table 1. Comparison of size of common street lighting core parameters

\begin{tabular}{ccc}
\hline Parameters & Survey results & Prototype size plan \\
\hline The width of the road & $7 \mathrm{~m}$ & $18 \mathrm{~cm}$ \\
Distance between lights & $30 \mathrm{~m}$ & $20 \mathrm{~cm}$ \\
High light pole & $8 \mathrm{~m}$ & $20 \mathrm{~cm}$ \\
Lamp power & $90 \mathrm{watts}$ & $1 \mathrm{watt}$ \\
\hline
\end{tabular}

The data in Table 1 is used to design the prototype of smart street lighting. After the prototype of street lighting was completed, the design of the IoT began. The IoT circuit and working principle for street 
lighting are shown in Figure 2. Based on Figure 2(a) number 1 can be noted that NodeMCU ESP8266 is in the middle as a processor and provider of data from other components for the Cayenne Android application. The components are divided into 2 parts, namely input, and output. The input part consists of a sensor consisting of light intensity BH1750FVI which is given numbers 3-6 to read the intensity of incoming light, $\mathrm{Wi}-\mathrm{Fi}$ as a network that is used is integrated with NodeMCU ESP8266. The output part consists of relay number 2 and lamp number 7-10. Figure 2(b) shows the working principle, the compilation of ESP8266 gets the source and command, then the processor in ESP8266 begins to prepare the processing.

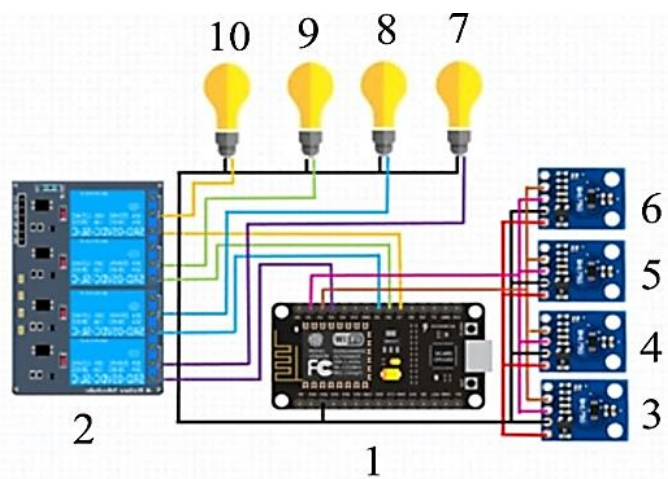

(a)

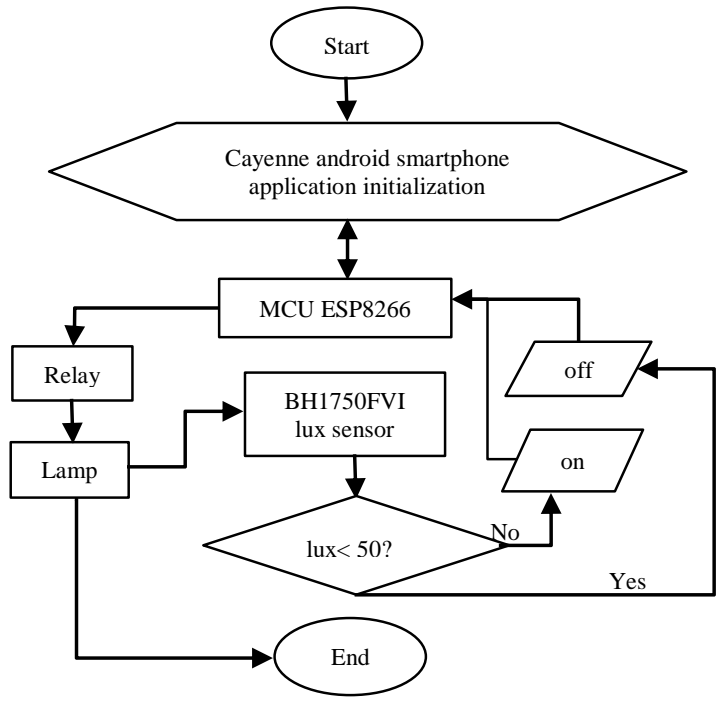

(b)

Figure 2. Design of system: (a) circuit and (b) flowchart IoT working principles for smart street lighting

When pressing the button on the cayenne application is pressed (given a high logic) the ESP will send data to the relay. Based on the data received the relay works to receive the lamp. The BH1750FVI sensor will continue to read the light intensity issued by the lamp and will request the cayenne application on an Android smartphone. If pressing the button on a supported application (given high logic) the light contained in the cayenne application does not match or is less than the specified value, the lamp status is not lit and can be considered as proof of damage to the lamp. If the value obtained is equal to or the specified value, then the light status is determined, and by the data read in the cayenne application, the lamp is estimated to work well.

This section works by reading the light intensity by the LDR sensor. Outside light conditions are read by the LDR whether in a state of high light intensity (bright) or low light intensity (dark) if the sensor gives a signal that the conditions are dark outside then the lamp conditions will light with low intensity (dim) followed by an ultrasonic sensor reading to detect the existence of a human or vehicle, if there is a human or vehicle that is read by an ultrasonic sensor then the sensor will send a signal to Arduino to process the light automatically according to the specified level and will dim after the vehicle passes the read sensor capability. the whole process was designed with the fuzzy logic method. The fuzzy set design in Table 2 shows the intervals for each condition for three variables, namely: light intensity, road conditions, and lamps.

Table 2. Fuzzy set design

\begin{tabular}{cccc}
\hline Variable Name & Set Name & Unit & Interval \\
\hline \multirow{2}{*}{ Light intensity } & High & \multirow{2}{*}{ [high, Low (dark)] } & {$[0,25,55]$} \\
& Dim/dark & & {$[45,70,100]$} \\
& Empty & & {$[0,15,35]$} \\
Road condition & Pedestrian & [quiet, there are pedestrians, there is a vehicle] & {$[30,45,65]$} \\
& Vehicle & & {$[60,80,100]$} \\
& Dark & & {$[0,15,35]$} \\
Lamp & Dim & [dark, dim, light] & {$[30,45,65]$} \\
& Light & & {$[60,80,100]$} \\
\hline
\end{tabular}




\section{RESULTS AND ANALYSIS}

The prototype with the size in Table 1 has been completed as shown in Figures 3(a) and (b) which are the smart street lighting prototypes for layout and 3D design, respectively. This prototype consists of public roads, sidewalks, street lighting, NodeMCU ESP8266, BH1750FVI lux sensors, LDR sensors, ultrasonic sensors, and cayenne android application.

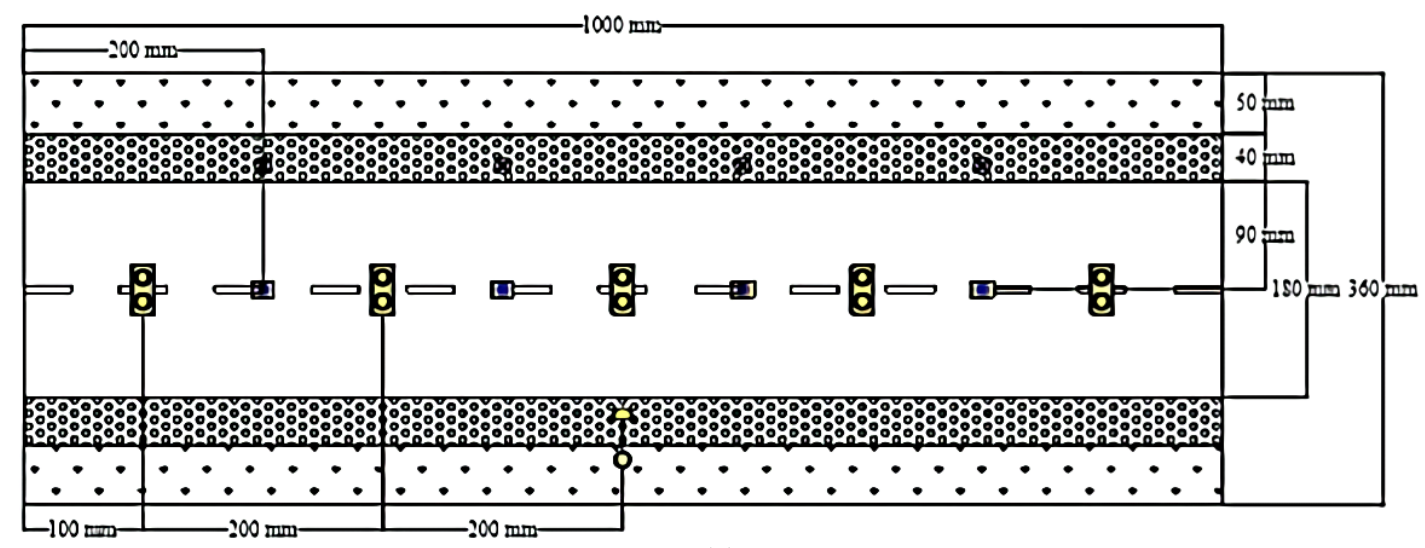

(a)

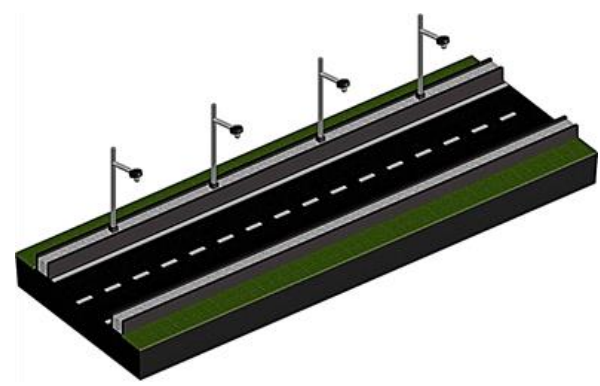

(b)

Figure 3. Smart street lighting prototypes: (a) layout and (b) 3D design

\subsection{Testing for IoT}

This test is carried out to determine the efficiency of the remote device and the average result of data transmission in applications covering all aspects, namely, the response of the lights on (L), the status of the lamp (SL), and the reading of lux (Lx) on each lamp, only with different locations, namely location 1 at the Kembang Kuning village office $(1.1 \mathrm{~km})$, location 2 at the Selaeurih gas station $(1.3 \mathrm{~km})$, location 3 at the Parcom gas station $(2.1 \mathrm{~km})$, location 4 at SMPN 4 Purwakarta $(2.7 \mathrm{~km})$, location 5 in Taman Pembaharuan $(3.6 \mathrm{~km})$ and location 6 in STS Sadang $(6.9 \mathrm{~km})$ with Internet connection outside of different networks installed on ESP8266. Table 3 shows the test results.

Table 3. System response test result

\begin{tabular}{cccccccccc}
\hline \multirow{2}{*}{ Testing No. } & \multicolumn{7}{c}{ Response (s) } \\
\cline { 2 - 10 } & L1 & SL1 & Lx1 & L2 & SL2 & Lx2 & L3 & SL3 & Lx3 \\
\hline 1 & 1,7 & 17,1 & 10,7 & 1,8 & 16,9 & 20 & 1,6 & 15,8 & 18,6 \\
2 & 2 & 14,1 & 13 & 1,6 & 17,2 & 3,3 & 2,2 & 18,9 & 6,6 \\
3 & 1,8 & 14,7 & 11,5 & 2,3 & 9,8 & 6,9 & 1,6 & 21,6 & 6,7 \\
4 & 2 & 20,2 & 4,6 & 1,9 & 10,3 & 4,4 & 2,3 & 20,6 & 3,8 \\
5 & 2,8 & 19 & 15,5 & 3 & 17,3 & 5,7 & 3,4 & 14,7 & 7,11 \\
6 & 1,8 & 11,2 & 11 & 2 & 21,9 & 6,5 & 12,8 & 18,7 & 19,6 \\
Average & 2 & 16 & 11 & 2,1 & 15,5 & 7,8 & 4 & 18,3 & 10,4 \\
\hline
\end{tabular}

The average primary reaction time (L1, L2, L3) of adjustment to lamps 1,2 , and 3 is $2,2.1$, and 4 seconds (s) in the test results presented in Table 3. The average response time of lamp status (SL1, SL2, SL3) application to lamps is $16,15.5$, and $18.3 \mathrm{~s}$. The average response times for lux readings $(\mathrm{Lx} 1, \mathrm{Lx} 2, \mathrm{Lx} 3)$ in 
applications to lamps are 11, 7.8, and 10.4 s. Figure 4 shows the appearance of the Cayenne application during testing.

This test aims to determine whether SL and Lx in the application are functioning properly as an indication of damage to the lamp. From the results of this test, the results obtained in Table 4 . Where in this test it can be concluded at number 1 there are no indications of damage to lamps 1,2 , and 3 while at number 2 there is an indication of damage to lamp 1 because at Lx 1 there is a value of 0 lux and lamp status is OFF (does not change color) because the lamp does not light up so the lx does not read and the status lights do not work. Figures 4(a) and (b) show the appearance of the android application for the condition of all lights are on and one 1 light is off, respectively.

Table 4. Lamp status reading test

\begin{tabular}{cccccccccc}
\hline No & L1 & SL1 & Lx1 & L2 & SL2 & Lx2 & L3 & SL3 & Lx3 \\
\hline 1 & ON & ON & $2731 x$ & ON & ON & $1161 x$ & ON & ON & $1121 x$ \\
2 & ON & OFF & 0 & ON & ON & $1151 x$ & ON & ON & $1121 x$ \\
\hline
\end{tabular}

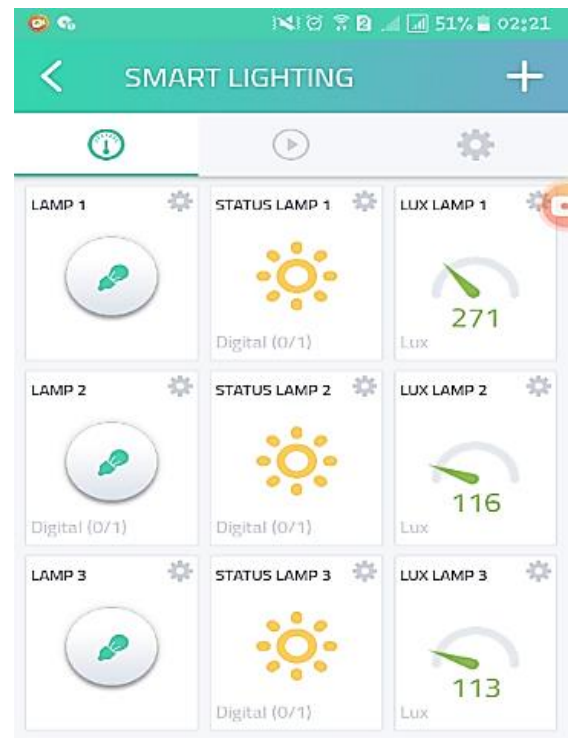

(a)

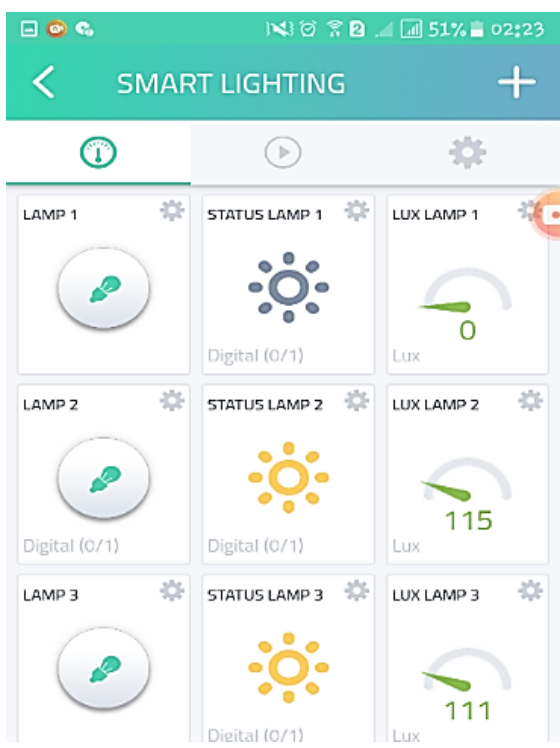

(b)

Figure 4. Android application, (a) condition all lights are on and (b) 1 light is off

\subsection{Fuzzy logic testing}

Control system testing with fuzzy logic consists of testing BH1750 lux sensor functions and ultrasonic sensor testing. BH1750 lux sensor testing is performed to read the light intensity conditions on public roads by detecting the light intensity. Ultrasonic sensor testing is carried out to control lighting on public roads by detecting the presence of pedestrians or vehicles. Both test results are shown in Table 5.

Table 5. Fuzzy logic testing

\begin{tabular}{ccc}
\hline Lux sensor & Ultrasonic sensor & Lamp \\
\hline High light intensity & Quiet street & Off \\
High light intensity & There are pedestrians & Off \\
High light intensity & There is a vehicle & Off \\
Low light intensity (dark) & Quiet street & Dim \\
Low light intensity (dark) & There are pedestrians & Light \\
Low light intensity (dark) & There is a vehicle & Light \\
\hline
\end{tabular}

The test results of applying the planned fuzzy rules will be seen in table 5, especially: 1) if (lux sensor is high) and (ultrasonic sensor is quiet) then (light is off), 2) if (sensor lux is high) and (lux sensor is pedestrian) then (light is off), 3 ) if (sensor lux is high) and (sensor lux is no vehicle) then (light is off), 4) if (sensor lux is dark) and (lux sensor is quiet) then (light is dim), 5) if (lux sensor is dark) and (lux sensor is 
pedestrian) then (light is bright), 6) if (lux sensor is dark) ) and (sensor lux is no vehicle) then (light is bright).

\subsection{Smart street lighting system functional test results and discussion}

The smart street lighting system functional test results as shown in Figure 5 show all monitoring and control functions with IoT and fuzzy logic operate as intended as shown in Figure 5(a) test results when the condition is there a vehicle and Figure 5(b) read the status of the lights through a smartphone. Previous studies have completed a prototype for regulating light intensity using passive infrared (PIR), ultrasonic, LDR, and ZigBee modules [22]-[25]. Several other studies have solved the problem of monitoring using IoT. The results of this research combine fuzzy light control with monitoring using IoT. The monitoring system monitors the light state, the strength of light, and also predicts light harm. Control can be done remotely via the Internet. Fuzzy control of the light's intensity has shown results following the design. Table 6 shows the results of the comparison of monthly energy consumption between the fuzzy system and the proposed fuzzy system.

Table 6. Comparison of monthly electrical energy consumption on prototypes

\begin{tabular}{ccc}
\hline & Non-fuzzy & Fuzzy proposed \\
\hline Electric energy consumption & $268,56 \mathrm{Wh}$ & $135,5 \mathrm{Wh}$ \\
Saving percentage with fuzzy & & 49.55 \\
\hline
\end{tabular}

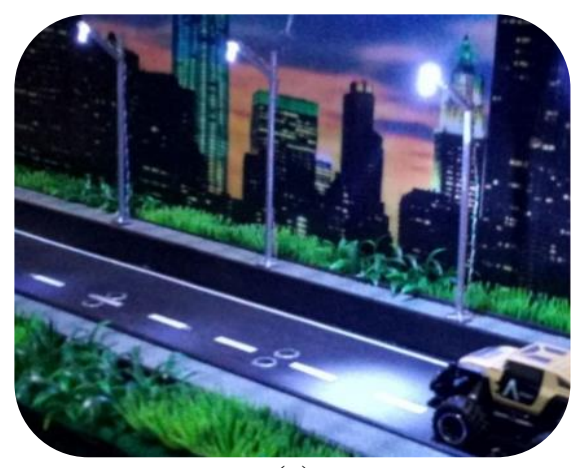

(a)

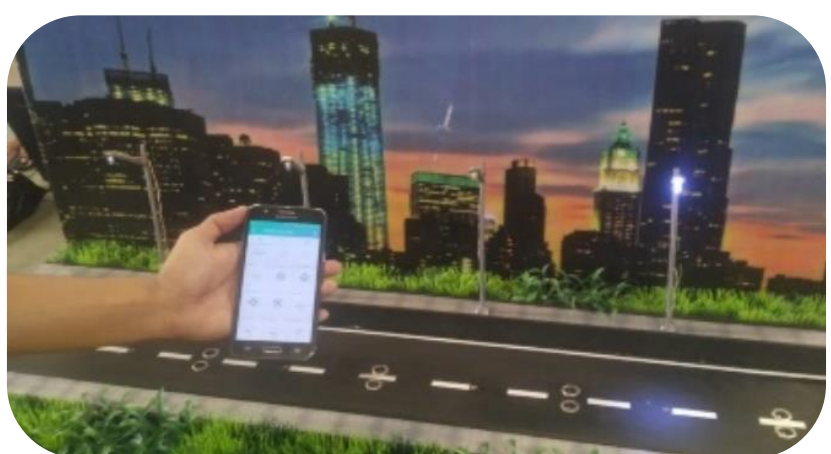

(b)

Figure 5. Test result of (a) the conditions when there is a vehicle and (b) read the status of the lights through a smartphone

\subsection{Energy-saving analysis}

In this prototype the electric current in the lamp when it is bright is $200 \mathrm{~mA}$ with a voltage of 3.73 $\mathrm{V}$, the duration of the lamp turns on at night for 12 hours, and the number of days in a month is 30 days. The power consumed is $746 \mathrm{~mW}$. The electrical energy consumed each month on this prototype is $0.746 \mathrm{x} 12$ hours x 30 days, which is 268.56 Watt-hours (Wh). As in previous studies, energy conservation is part of this study's intent [26].

Three lighting requirements arise with the use of fuzzy logic in the prototype. The lamp is in dim condition with a voltage of $0.17 \mathrm{~V}$ and a current of $40 \mathrm{~mA}$, a light condition with a voltage of $3.73 \mathrm{~V}$ and a current of $200 \mathrm{~mA}$, and a dead condition at a voltage and current 0 . The length of the lamp is 12 hours at night, and the number of days every month is 30 days. The power consumed during the dim is $6.8 \mathrm{~mW}$ and the light is $746 \mathrm{~mW}$. The electrical energy consumed each month on this prototype when dim is $6.8 \mathrm{~mW} \times 6$ hours x 30 days, which is $1.22 \mathrm{Wh}$. Power is consumed in the light of $746 \mathrm{~mW}$. The electricity consumed every month on this prototype is $746 \mathrm{~mW}$ x 6 hours $\mathrm{x} 30$ days, which is $134.28 \mathrm{Wh}$. The total consumption of electrical energy using fuzzy logic is $135.5 \mathrm{Wh}$. The percentage of savings is 49.55 . Comparison of monthly electrical energy consumption on prototypes shown in Table 6.

\section{CONCLUSION}

The prototype of smart street lighting has been created and the performance has been evaluated. IoT has been used for functions that consist of reading the value of the light intensity, lamp status, and instructions for turning on or turning off the lights can be done through the cayenne app on the android 
smartphone. The light intensity has also been controlled fuzzy based on the presence of vehicles and pedestrians. Compared to use without fuzzy logic, an energy-saving study of the prototype suggests that 49.55 percent of electricity consumption can be avoided.

\section{ACKNOWLEDGMENTS}

Authors wishing to acknowledge the Directorate General of Strengthening Research and Development at the Ministry of Research, Technology, and Higher Education, Republic of Indonesia for the support of this research with grant Penelitian Kerjasama Perguruan Tinggi 2019 and my three students namely Dian, Wina, and Meydina who assisted this research.

\section{REFERENCES}

[1] H. Ahmad, K. Naseer, M. Asif, and M. F. Alam, "Smart Street light system powered by footsteps," Proc. - 2019 7th Int. Conf. Green Hum. Inf. Technol. ICGHIT 2019, pp. 122-124, 2019, doi: 10.1109/ICGHIT.2019.00036.

[2] D. K. Srivatsa, B. Preethi, R. Parinitha, G. Sumana, and A. Kumar, "Smart street lights," Proc. - 2013 Texas Instruments India Educ. Conf. TIIEC 2013, pp. 103-106, 2013, doi: 10.1109/TIIEC.2013.25.

[3] S. G. Varghese, C. P. Kurian, V. I. George, A. John, V. Nayak, and A. Upadhyay, "Comparative study of zigBee topologies for IoT-based lighting automation,” IET Wirel. Sens. Syst., vol. 9, no. 4, pp. 201-207, 2019, doi: 10.1049/iet-wss.2018.5065.

[4] A. Farahat, A. Florea, J. L. M. Lastra, C. Brañas, and F. J. A. Sánchez, "Energy Efficiency Considerations for LED-Based Lighting of Multipurpose Outdoor Environments," IEEE J. Emerg. Sel. Top. Power Electron., vol. 3, no. 3, pp. 599-608, 2015, doi: 10.1109/JESTPE.2015.2453231.

[5] A. Abdullah, S. H. Yusoff, S. A. Zaini, N. S. Midi, and S. Y. Mohamad, "Smart Street Light Using Intensity Controller," Proc. 2018 7th Int. Conf. Comput. Commun. Eng. ICCCE 2018, pp. 361-365, 2018, doi: 10.1109/ICCCE.2018.8539321.

[6] S. Kumar, A. Deshpande, S. S. Ho, J. S. Ku, and S. E. Sarma, "Urban Street Lighting Infrastructure Monitoring Using a Mobile Sensor Platform," IEEE Sens. J., vol. 16, no. 12, pp. 4981-4994, 2016, doi: 10.1109/JSEN.2016.2552249.

[7] F. Leccese, "Remote-control system of high efficiency and intelligent street lighting using a zig bee network of devices and sensors," IEEE Trans. Power Deliv., vol. 28, no. 1, pp. 21-28, 2013, doi: 10.1109/TPWRD.2012.2212215.

[8] M. Eriyadi, A. G. Abdullah, S. B. Mulia, and H. Hasbullah, "Street lighting efficiency with particle swarm optimization algorithm following Indonesian standard," J. Phys. Conf. Ser., vol. 1402, no. 4, 2019, doi: 10.1088/1742-6596/1402/4/044009.

[9] F. Kamaruddin, N. N. Nik Abd Malik, N. A. Murad, N. M. Abdul Latiff, S. K. S. Yusof, and S. A. Hamzah, "IoTbased intelligent irrigation management and monitoring system using Arduino," TELKOMNIKA (Telecommunication Comput. Electron. Control., vol. 17, no. 5, p. 2378, 2019, doi: 10.12928/telkomnika.v17i5.12818.

[10] G. Shahzad, H. Yang, A. W. Ahmad, and C. Lee, "Energy-Efficient Intelligent Street Lighting System Using Traffic-Adaptive Control," IEEE Sens. J., vol. 16, no. 13, 2016, doi: 10.1109/JSEN.2016.2557345.

[11] M. Caroline Viola Stella Mary, G. Prince Devaraj, T. Anto Theepak, D. Joseph Pushparaj, and J. Monica Esther, "Intelligent energy efficient street light controlling system based on IoT for smart city," Proc. Int. Conf. Smart Syst. Inven. Technol. ICSSIT 2018, no. Icssit, pp. 551-554, 2018, doi: 10.1109/ICSSIT.2018.8748324.

[12] R. R. Mohamed, M. A. Mohamed, A. Ahmad, and M. A. H. Abd Halim, "Provisioning of street lighting based on ambience intensity for smart city," Indones. J. Electr. Eng. Comput. Sci., vol. 12, no. 3, pp. 1401-1406, 2018, doi: 10.11591/ijeecs.v12.i3.pp1401-1406.

[13] R. B. Caldo et al., "Design and development of fuzzy logic controlled dimming lighting system using Arduino microcontroller," 8th Int. Conf. Humanoid, Nanotechnology, Inf. Technol. Commun. Control. Environ. Manag. HNICEM 2015, no. December, pp. 0-5, 2016, doi: 10.1109/HNICEM.2015.7393161.

[14] D. Hartanti, R. N. Aziza, and P. C. Siswipraptini, "Optimization of smart traffic lights to prevent traffic congestion using fuzzy logic," Telkomnika (Telecommunication Comput. Electron. Control., vol. 17, no. 1, pp. 320-327, 2019, doi: 10.12928/TELKOMNIKA.v17i1.10129.

[15] K. Choeychuen, "Fuzzy membership function optimization for smart LED lamp using particle swarm optimization," 2018 Int. Work. Adv. Image Technol. IWAIT 2018, pp. 1-4, 2018, doi: 10.1109/IWAIT.2018.8369808.

[16] R. Lohote, T. Bhogle, V. Patel, and V. Shelke, "Smart Street Light Lamps," 2018 Int. Conf. Smart City Emerg. Technol. ICSCET 2018, pp. 1-5, 2018, doi: 10.1109/ICSCET.2018.8537304.

[17] S. Yoomak and A. Ngaopitakkul, "Investigation and Feasibility Evaluation of Using Nanogrid Technology Integrated into Road Lighting System," IEEE Access, vol. 8, pp. 56739-56754, 2020, doi: 10.1109/ACCESS.2020.2978897.

[18] J. Higuera, W. Hertog, M. Perálvarez, J. Polo, and J. Carreras, "Smart lighting system ISO/IEC/IEEE 21451 compatible," IEEE Sens. J., vol. 15, no. 5, pp. 2595-2602, 2015, doi: 10.1109/JSEN.2015.2390262.

[19] G. Parise, L. Parise, and L. De Rosa, "Electrical Safety in Street Lighting Systems Against Loss of Service 
Continuity and Shock Hazards," IEEE Trans. Ind. Appl., vol. 54, no. 6, pp. 5711-5716, 2018, doi: 10.1109/TIA.2018.2861406.

[20] T. Ankalkote and V.B.Shere, "Modern LED Street Lighting System with Intensity Control Based on Vehicle Movements and Atmospheric Conditions Using WSN," Int. J. Innov. Res. Adv. Eng., vol. 3, no. 05, pp. 10-15, 2016, doi: doi:10.17632/v8s6m3fy78.1.

[21] A. Abdullah, S. H. Yusoff, S. A. Zaini, N. S. Midi, and S. Y. Mohamad, "Energy efficient smart street light for smart city using sensors and controller," Bull. Electr. Eng. Informatics, vol. 8, no. 2, pp. 558-568, 2019, doi: 10.11591/eei.v8i2.1527.

[22] R. K. Sadar, A. M. Someshwar, and R. P. Chaudhari, "Load Cell Based Cross Verification of Packaging Material," pp. 460-463, 2017.

[23] Z. Kaleem, T. M. Yoon, and C. Lee, "Energy Efficient Outdoor Light Monitoring and Control Architecture Using Embedded System," IEEE Embed. Syst. Lett., vol. 8, no. 1, pp. 18-21, 2016, doi: 10.1109/LES.2015.2494598.

[24] Y. E. Wu and K. C. Huang, "Smart household environment illumination dimming and control," IEEE/OSA J. Disp. Technol., vol. 11, no. 12, pp. 997-1004, 2015, doi: 10.1109/JDT.2015.2455152.

[25] M. Magno, T. Polonelli, L. Benini, and E. Popovici, "A low cost, highly scalable wireless sensor network solution to achieve smart LED light control for green buildings," IEEE Sens. J., vol. 15, no. 5, pp. 2963-2973, 2015, doi: 10.1109/JSEN.2014.2383996.

[26] Y. S. Yang, S. H. Lee, G. S. Chen, C. S. Yang, Y. M. Huang, and T. W. Hou, "An Implementation of High Efficient Smart Street Light Management System for Smart City,” IEEE Access, vol. 8, pp. 38568-38585, 2020, doi: 10.1109/ACCESS.2020.2975708.

\section{BIOGRAPHIES OF AUTHORS}

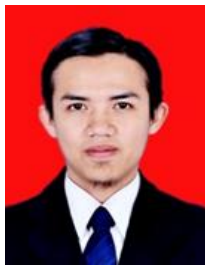

Mindit Eriyadi obtained her Master of Science in Electrical Engineering from Institut Teknologi Bandung, Indonesia. He is currently an Assistant Professor at the Department of Electrical Engineering, Politeknik Enjinering Indorama. His research interests are automation, computation, electricity and energy management and audit.

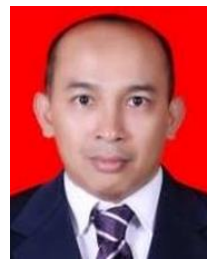

Ade Gafar Abdullah received a Doctor Degree in Physic from Institut Teknologi Bandung, Indonesia in 2011, respectively. He has been appointed as a Professor in the Department of Electrical Engineering, Faculty of Technology and Vocational Education, Universitas Pendidikan Indonesia. His current research interests include soft computing, nuclear physic, and electrical engineering education.

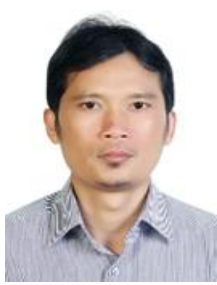

Hasbullah received a Doctor Degree in Vocational and Education Technology from Universitas Pendidikan Indonesia and Master of Engineering in Electrical Engineering from Universitas Gajah Mada, Indonesia in 2014 and 2006, respectively. He has been appointed as an Associate Professor in the Department of Electrical Engineering, Faculty of Technology and Vocational Education, Universitas Pendidikan Indonesia. His current research interests electrical engineering and power system.

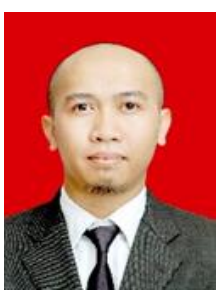

Sandy Bhawana Mulia obtained her Master of Science in Electrical Engineering from Institut Teknologi Bandung, Indonesia. He is currently an Assistant Professor at the Department of Manufacturing Automation Engineering and Mechatronics, Politeknik Manufaktur Bandung. His research interests are control and power system. 